\title{
Evaluation of a Risk Rating Instrument in the Reception a Hospital Unit of South Central Ceará

Amanda Soares ${ }^{1}$, Tito Lívio Ribeiro Gomes do Nascimento ${ }^{2}$, Thiago Lívio Barbosa Pereira ${ }^{3}$, Angélica da Silva Soares ${ }^{4}$, Ana Cláudia Martins Rodrigues ${ }^{3}$, Najara Rodrigues Dantas ${ }^{1}$, Francisco Fernandes Abel Mangueira ${ }^{3}$, Flaviana Dávila de Sousa Soares ${ }^{5}$, Ícaro Tavares Borges ${ }^{1}$,

Bárbara Letícia de Queiroz Xavier³, Paula Frassinetti Oliveira Cezário6, José Iran Oliveira das Chagas Júnior7, Maria Enói Gadelha Vale Vírginio4, Danielly Gonçalves da Siva ${ }^{8}$, Antônio Carlos Alves Cartaxo ${ }^{3}$, Alba Benemérita Alves Vilela², Marta Kelly Batista Fiuza9

\section{Abstract}

Introduction: Reception with Risk Rating consists of strategies that ensure the inclusion of Humanization in health and reduces negative health indicators.

Objective: To analyze the composition of the reception sheet of a hospital located in south-central Ceará.

Method: This is a documental research, exploratory and descriptive with a qualitative approach.

Results: After documentary analysis of the report is concluded that the composition of this meets the needs of the initial evaluation of the patient.

Conclusion: It becomes necessary to its reformulation of the reception sheet, as there is a shortage of some items, such as vital signs. The changes suggested optimize the quality of assistance in the reception.

\section{Keywords}

Reception; Clinical sheet; Humanization of assistance.
1 Regional University of Cariri/ Decentralized Unit of Iguatu. Iguatu, Ceara, Brazil.

2 Postgraduate program (scrito sensu) in Nursing, University of Southwest Bahia. Jequie, Bahia, Brazil.

3 Bachelor of Nursing, Federal University of Campina Grande. Cajazeiras, Paraiba, Brazil.

4 Academic of Physical Therapy, Santa Maria College. Cajazeiras, Paraiba, Brazil.

5 Graduate student in Intensive Care Unit, Santa Maria College. Cajazeiras, Paraiba, Brazil.

6 Specialist, Federal University of Paraíba. João Pessoa, Paraiba, Brazil.

7 Graduate program (lato sensu) in Public Health, University of Fortaleza. Fortaleza, Ceara, Brazil.

8 Bachelor of Nursing, College Leão Sampaio. Juazeiro do Norte, Ceara, Brazil.

9 Graduate programs (lato sensu) in the Intensive Care Unit, University Vale do Acaraú. Iguatu, Ceara, Brazil.

Contact information:

Thiago Lívio Barbosa Pereira.

\section{Introduction}

The context of the medical conditions in Brazil has been transformed in recent decades due to urban population growth, tied to a process 
of industrialization and guarantee of health rights, providing opportunities for disadvantaged classes of accessibility to several social goods [1]. The rates of acute and transmissible chronic illnesses in Brazil reduced significantly by incorporating a new characterization of the social determinants of health. However, currently, the main source of disease burden is attributed to chronic diseases classified as a public health problem and threat to the health process of individuals. The increase in morbidity and mortality rates resulting from external causes such as homicides, domestic violence and traffic-related injuries is a concern for the health of the population as a result of its accelerated growth [2-4].

The number of attendances at health facilities, either primary care or secondary care, increased, overloading the system and, above all, directly interfering with quality of services provided. In order to prevent, control hazards in health and improve the quality of actions, public policies and strategies have been implemented in the health services, and the use of methods for the reception with the classification of risk $[3,5]$.

The Reception with Risk Rating (RR) is a device that composes strategies used in ensuring the insertion of humanization in health and also to reduce the negative health indicators. It is still considered as a technical assistance action that allows the change in the doctor-patient relationship, ensuring the active participation of all in the health production process. This organization implies providing an attendance with responsibility and problem solving to those who seek the health service, welcoming their needs in fulfilling the principles of the Unique System of Health (USH) [6-7].

The strategy of reception allows the rating of risks and causes related to biological and psychosocial factors that are determinants of a large quantity of clinical complaints and emergencies. The Conduction of RR not only covers the use of care, but also the organization of entry into the health system, implementing multiprofessional assistance, excluding the definition of the access through lines and order of arrival [8].

This risk rating process enables the identification of those patients who need immediate care according to the risk and degree of suffering. Priorities are set according to specific needs, differentiating by color system, being the red color an indicative of emergency, the yellow urgency, the green color is not urgent priority and the blue color indicates consultation of no urgent priority [9].

This color system will be conducted upon presentation of clinical complaints, guided by the signs and symptoms, which indicate the health professional to the appropriate level of care. Therefore, it is necessary to use a technical protocol built according to the peculiarities of the institution and grounded on scales or existing protocols such as Manchester Triage System (MTS), Canadian Emergency Department Triage and Acuity Scale (CATAS), Emergency Severity Index (ESI) and Australasian Triage Scale (ATS) [10].

The RR is similar to the nursing consultation, covering the investigation stage, physiological, biological and social aspects, being a private assignment of nurses as expressed in the Article $1^{\text {st }}$ of COFEN Resolution 423/2013 [11].During the RR, interview, checking of vital signs, simple physical examination, and if necessary, further examination with electrocardiogram and blood glucose should be conducted. Based on the data collected, the nurse should formulate a clinical and critical judgment of the case, backed by the treatment protocol [12].

Thus, the RR should be built and performed aiming at the solving of problems of patients seeking care in health services, being the same, based on the analysis of cases such as the entry of patients, covered steps, output and results achieved, in a way that each stage of the work process stream will be analyzed [7].

The construction of the data collection sheets as well as the flowchart are essential items in customer risk rating, favoring the quality of care and ensu- 
ring the fulfillment of public policies. Because of its relevance, the following question arises: Are the compositions of these items satisfactory to the point of maintain quality in patient assistance?

Therefore, in order to broaden the discussion over the sheet's data structure, this study aims to analyze the composition of an RR medical sheet from a small hospital, located in a city in the countryside of Ceará.

\section{Method}

This is a documentary, exploratory and descriptive study with a qualitative approach conducted in the municipality of Várzea Alegre, located in the south central region of the state of Ceará. The documentary research involves the study of documents that have not yet received analytical treatment and allows the investigation of certain issues indirectly, through the study of documents that are produced by man [13].

The qualitative research is based on answering particular questions, either individually or collectively, addressing meanings, motives, values, culture, in order to explore the environment and/or the situation studied [14].

The source of the survey data was the reception sheet used in the emergency and ambulatory sector of Municipal Hospital São Raimundo Nonato, which are addressed through document analysis being grounded and confronted with the pertinent literature. The period of the collection was from June to July 2015, receiving direction from the institution, according to the attendance of all the guidelines contained in the Resolution N.466/2012 of the National Health Council [15].

\section{Results}

\section{Categories of documental analysis}

From the analysis of the sheet of Risk Rating (Figure 1), it was possible to identify four categories:
Figure 1: Risk Rating Sheet.

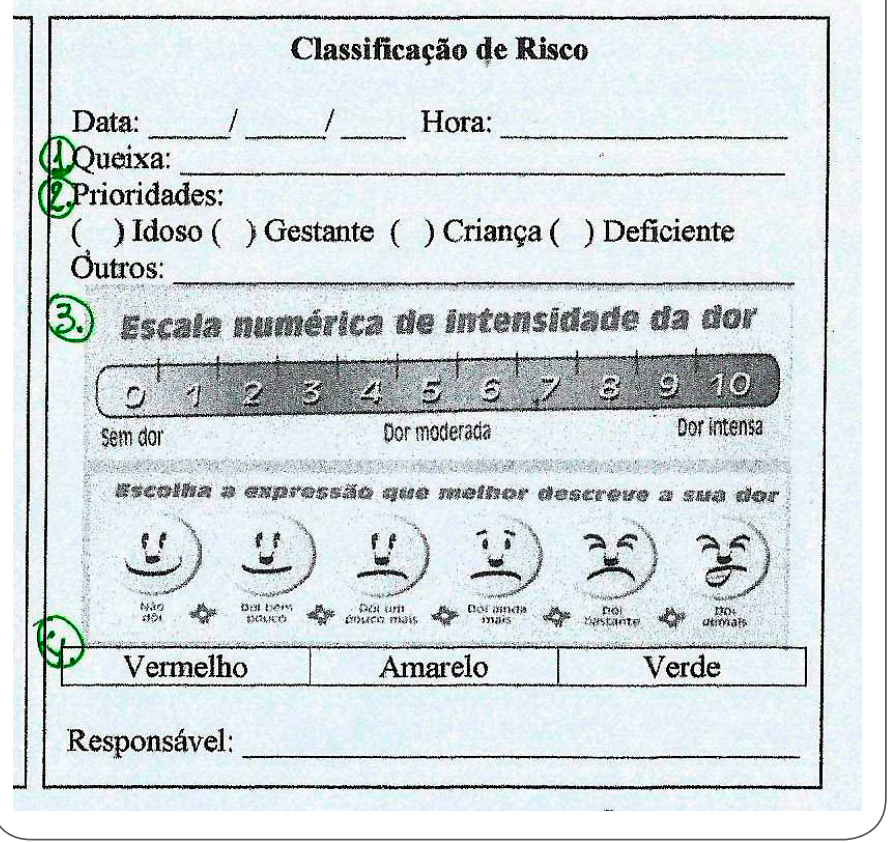

Complaints, Priorities, Pain Intensity Scale (PIS), and Classification: Red, Yellow and Green.

Category 01. Complaints.

One can consider the item "Complaint" as the main guiding and mediator of assistance, promoting a direction to the nursing professional to start the consultation.

Category 02. Priorities.

The item "Priorities" establishes the groups with preference for assistance, which are pregnant women, elderly, disabled and children.

Category 03. Pain Intensity Scale (PIS).

The third category evaluates, in numerical form and in relation to the report of the patient, the intensity of pain, ranging from No pain (zero), Moderate pain (1 to 5 ) and Intense pain (6 to 10).

Category 04. Classification: Red, Yellow and Green. The adoption of the risk rating protocol allows the systematization of initial patient assistance, identifying it with a color that corresponds to clinical severity in patients. 


\section{Discussion}

The risk rating consultation begins when the user goes to the health facility in order to get resolvability to his problem. The nursing professional is responsible for implementing this reception by performing the correct identification of the complaint and ensuring an organized form of assistance, which provides the prevention of iatrogenic by manipulation or incorrect treatments, thus avoiding the death or development of temporary or permanent physical incapacities [16].

During reception, knowledge of the patient's life history is also necessary, respecting the diversity of cultures and customs present in each individual's daily life, which promotes a holistic approach to the patient [17].

The human being is defined by its multidimensionality which includes biological, psychological, social, emotional and rational aspects. However, what occurs mainly in emergency departments is the conduct of some professionals focused on biological aspects, without considering the other dimensions, therefore, noticeable fragmentation of care [18].

The initial user assistance in hospital services aims to identify problems using clinical criteria, which prioritize a care based on the severity of the condition, risk potential and/or degree of suffering, aimed at ensuring greater quality of care. Therefore, it becomes essential to use strategies that enforce the reasoned clinical care in identifying the "Complaints", as shown in Category 1, and also provide a holistic and humanized assistance to patients [19].

Among the points that must address professional practice in the identification of complaints, the material resources and trained human resources are considered indispensable. The expansion of policies and guidelines that encourage capacity building for all categories of professional, demonstrates the State's concern to qualify health care through continued education [20].

With regard to Category 02 "Priorities", the system of laws in Brazil calls for a preference in care for the elderly, disabled, pregnant women and persons conducting infants, being established by Law $\mathrm{N}^{\circ}$. 10048/2000, which the public offices and utility companies are obliged to dispense with priority assistance to these groups, because these individuals are or have higher tendency to physical vulnerability and/or health [21].

It is noteworthy that the risk rating sheet is used in the emergency sector, where this criterion of priorities is rarely used because when dealing with cases of urgency and emergency, the conduct must be differentiated, being the form of organized service of those cases of imminent risk to be prioritized over the other [22].

Defining a framework in urgency or emergency is quite complex and requires a skilled professional to act against such situations, given that this process involves the degree of knowledge, experiences and also the complexity of each event. Therefore, it is necessary that the practice of professional is not only linked to subjectivity or his experience, but based on a standardized consent USH of clinical protocols, which allow prevention of any inequality in the assistance provided [23].

The understanding of the aspects that involve the priorities of care aims to help identify the real health needs in the emergency services, without ignoring principles of humanization adopted by USH [24]. Decree No. 5.296/2004 [22] consolidates the obligation to run a assistance that prioritizes cases of emergency care for such groups considered most vulnerable, however, it emphasizes that situations of urgency and emergency to priority are conditional to clinical judgment.

About the Category "Pain Intensity Scale (PIS)", it is clear that this is a quantitative scale, of numeric type, in which the evaluation takes place according to the characterization: no pain, moderate pain and intense pain, ranging from 0 to 10 . The facial scale evaluates the face of the patient and a numerical value for the pain is stipulated [25].

The evaluation of the sign pain is subjective and complex as this cannot be measured in an examina- 
tion whatsoever, given that only the patient is able to set their intensity, being the professional responsible to understand the report of pain, identify their complaint and investigate data on related, personal and family factors [26-27].

The dynamic that involves identifying and control of pain is still important in this insertion, in the routine check of vital signs. The explanation is linked to the fact that researchers classify the pain as the fifth vital sign, then being primordial quantification and elucidation of its primary cause in the different attention levels [28].

Studies [29-30] on the PIS demonstrate that the main purpose of this tool is to obtain rapid information about pain intensity, facilitating the analgesic administration, promoting faster recovery and contributing to the patient's well-being.

In Category 4 "rating: Red, Yellow and Green", it is observed that the hospital under study only uses three colors, excluding blue. Most hospitals adopt the RR system in four colors, which are distributed in two axes. In the first axis, the red color signals patients with the risk of death, that require immediate assistance; the yellow color indicates critical or semi critical patient that has his clinical framework stabilized, and the green color is designated to non urgent patients, but who require observation. In the second axis there is the color blue, which is designated for patients who do not have severe clinical framework, being referred for basic attention [31].

The use of classification standards makes it possible for different examiners to execute clinical research using the same parameters for all patients, which reduces the subjectivity bias for each reviewer [32]. According to the Reception Manual and Risk Rating in the Services of Urgency, provided by the Ministry of Health, the RR protocol must be inclusive for all, requiring that the assistance is constantly organized to ensure assistance to individuals in need [33].

A tool widely used in urgent and emergency services is the Manchester Triage System (MTS), which classifies patients into five levels of priority and has been indicated as standard protocol in hospitals and pre-hospital institutions from different countries. In Brazil, about 16 states have at least one health facility using the MTP [34].

Clinical decision-making constitutes one of the fundamental pillars of the RR and requires a scientific and practical basis by the nurse who is the professional responsible for such assignment. However, it emphasizes that the legislation designating the practice of these professionals in Brazil does not allow the execution of immediate treatment chosen by him, which limits their assistance and the provision of care [11, 35].

The knowledge and the organization of the risk rating system in Brazil highlights the need for standardization of protocols used in all health services, so there is a better assistance provided, providing a universal, comprehensive and equal attention for all individuals.

\section{Conclusion}

On the analysis of the RR sheet, the importance of their use for work efficiency and for health care is noted. The functionality of this tool allows the initial assistance to be holistic, addressing all indispensable aspects in the definition of their health status. However, for comprehensive and quality assistance to be carried out, it is necessary that the items that make up the sheet investigate all the necessary information to classify the potential risk of the patient.

The reformulation of the sheet being studied is perceived as essential, requiring the inclusion of items such as vital signs, capillary oxygen saturation, the Glasgow coma scale and revaluation schedule. Thus, it is concluded that by improving the RR instrument used and the incentive to carry out training for professionals working in the sector, there will be an improvement in the quality and speed of assistance, bringing benefits to managers, professionals and patients. 


\section{References}

1. Figueiredo NMA, Tonini T. SUS E PSF para Enfermagem: Práticas para o cuidado em Saúde Coletiva. São Caetano do Sul, SP: Yendis Editora; 2007.

2. Victora CG, Barreto ML, Leal MC, Monteiro CA, Schmidt MI, Pain J et al. Condições de saúde e inovações nas políticas de saúde no Brasil: o caminho a percorrer. Lancet [Internet], 2011; Supl Saúde no Brasil 6:90-102. DOI: 10.1016/S01406736(11)60055-X

3. Schimidt MI, Duncan BB, Silva GA, Menezes AM, Monteiro CA, Barreto SM. Doenças crônicas não transmissíveis no Brasil: carga e desafios atuais. Saúde no Brasil 4 [Internet], 2011. Available from: http://hdl.handle.net/123456789/222

4. Reichenheim ME, Souza ER, Moraes CL, Jorge MHPM, Silva CMFP, Minayo MCS. Violência e lesões no Brasil: efeitos, avanços alcançados e desafios futuros. The Lancet [Internet], 2011; 6736(11):75-89. Available from: http://www.escoladesaude. pr.gov.br/arquivos/File/Material 1 violencia Lancet.pdf

5. Bellucci Júnior JA, Matsuda LM. Implantação do Sistema Acolhimento com Classificação e Avaliação de risco e uso do Fluxograma Analisador. Texto Contexto Enferm [Internet], Florianópolis, 2012 Jan/Mar; 21(1):217-25. DOI: http://dx.doi. org/10.1590/S0104-07072012000100025

6. Ministério da Saúde (BR). Portaria GM n 1.863, de 29 de setembro de 2003 [Internet]. Institui a Política Nacional de Atenção às Urgências, a ser implantada em todas as unidades federadas. Legislação de Saúde. Ministério da Saúde. Brasília, DF; 2003. Available from: http://bvsms.saude.gov.br/bvs/ saudelegis/gm/2003/prt1863 2609 2003.html

7. Ministério da Saúde (BR). Humaniza SUS: Acolhimento com Avaliação e Classificação de risco: um paradigma ético-estético no fazer em saúde. Ministério da Saúde, Secretaria-Executiva, Núcleo Técnico da Política Nacional de Humanização. - Brasília: Ministério da Saúde; 2004. Available from: http://bvsms.saude. gov.br/bvs/publicacoes/acolhimento.pdf

8. Nonnenmacher CL, Weiller TH, Oliveira SG. Opiniões de usuários de saúde sobre o Acolhimento com Classificação de Risco. Rev Eletr Enf [Internet], 2012 Jul/Sep; 14(3):541-9. Available from: http://www.revistas.ufg.br/index.php/fen/article/view/13462

9. Goulart CB, Haddas MCL, Vannuchi MTO, Rossaneis MA. Acolhimento como estratégia para alcançar a integralidade da assistência em hospital de média complexidade. Semina: Ciências Biológicas e da Saúde [Internet], Londrina, 2013 Jan/Jul; 34(1):91-6. DOI: http://dx.doi.org/10.5433/1679$\underline{0367.2013 v 34 n 1 p 91}$

10. Oliveira KKD, Amorim KKPS, Fernandes APNL, Monteiro AI. Impacto da Implementação do Acolhimento com Classificação de risco para o trabalho dos Profissionais de uma Unidade de Pronto Atendimento. REME - Rev Min Enferm [Internet], 2013 Jan/mar; 17(1): 148-56. Available from: http://www.reme. org.br/artigo/detalhes/586
11. Conselho Federal de Enfermagem (COFEN). Resolução 423, de 15 de fevereiro de 2012 [Internet]. Normatiza, no âmbito do Sistema COFEN/COREN, a participação do Enfermeiro na Atividade de Classificação de Riscos. Available from: http://www.cofen.gov.br/resoluo-cofen-n-4232012 8956.html

12. Nascimento ERP, Hilsendeger BR, Neth C, Belaver GM, Bertoncello KCG. Acolhimento com classificação de risco: avaliação dos profissionais de enfermagem de um serviço de emergência. Rev Eletr Enf [Internet], 2011 Out/Dez; 13(4): 597603. Available from: http://www.revistas.ufg.br/index.php/fen/ article/view/11812

13. Silva LRC. Pesquisa documental: alternativa investigativa na formação docente. In: Congresso Nacional de Educação EDUCERE, IX, Encontro Sul Brasileiro de Psicopedagogia, III, 2009, Curitiba. Available from: http://www.pucpr.br/eventos/ educere/educere2009/anais/pdf/3124 1712.pdf

14. Duarte SJH, Mamede MV, Andrade SMO. Opções teóricometodológicas em pesquisas qualitativas: representações sociais e discurso do sujeito coletivo. Saúde Soc [Internet], São Paulo, 2009 Oct/Dez; 18(4):620-6. DOl: http://dx.doi. org/10.1590/S0104-12902009000400006

15. Ministério da saúde (BR). Conselho Nacional de Saúde. Comissão Nacional de Ética em Pesquisa. Normas regulamentadoras de pesquisa envolvendo seres humanos: Resolução 466/12. Brasília (DF): Ministério da Saúde; 2012.

16. Ministério da Saúde (BR). Ministério da Saúde. Política Nacional de Atenção às Urgências [Internet]. 3 ed. Ampl. - Brasília: Ministério da Saúde; 2006. Available from: http://bvsms. saude.gov.br/bvs/publicacoes/politica nacional atencao urgencias_3ed.pdf

17. Mitre SM, Andrade EIG, Cotta RMM. Avanços e desafios do acolhimento na operacionalização e qualificação do Sistema Único de Saúde na Atenção Primária: um resgate da produção bibliográfica do Brasil. Ciênc Saúde Coletiva [Internet] Rio de Janeiro, 2012 Aug; 17(8): 2071-85. DOI: http://dx.doi. org/10.1590/S1413-81232012000800018

18. Baggio MA, Callegaro GD, Erdmann AL. Compreendendo as dimensões de cuidado em uma unidade de emergência hospitalar. Rev Bras Enferm [Internet], Brasília, 2008 Set/Out; 61(5): 552-7. DOI: http://dx.doi.org/10.1590/S003471672008000500004

19. Hiestand MDB, Moseley M, Macwilliams B, Southwick J. The Influence of Emergency Medical Services Transport on Emergency Severity Index Triage Level for Patients With Abdominal Pain. Acad Emerg Med [Internet], 2011 Mar; 18(3): 261-6. DOI: 10.1111/j.1553-2712.2011.01005.x. 
20. Lúcio RR, Costa ACM. Urgências e Emergências Clínicas na Atenção Primária: conhecimento e atuação da equipe de enfermagem. Rev Enfermagem UFPI [Internet], Teresina, 2014 Jan/Mar; 3(1): 18-24. Available from: http://www.ojs.ufpi.br/ index.php/reufpi/article/view/1135

21. Ministério da Saúde (BR). Lei 10.048 de 08 de novembro de 2000 [Internet]. Available from: http://www.planalto.gov.br/ ccivil 03/LEIS/L10048.htm.

22. Ministério da Saúde (BR). Decreto 5.296 de 02 de dezembro de 2004 [Internet]. Available from: http://www.planalto.gov.br/ ccivil 03/ato2004-2006/2004/decreto/d5296.html

23. Lumer S, Rodrigues PHA. O papel da saúde da família na atenção às urgências. Rev APS [Internet], 2011 Jul/Set; 14(3): 289-95. Available from: http://aps.ufjf.emnuvens.com.br/aps/ article/view/898

24. Versa GLGS, Vituri DW, Buriola AA, Oliveira CA, Matsuda LM. Avaliação do acolhimento com classificação de risco em serviços de emergência hospitalar. Rev Gaúcha Enferm [Internet], 2014 Set; 35(3): 21-8. Available from: http://seer.ufrgs.br/index.php/ RevistaGauchadeEnfermagem/article/view/45475

25. Amthauer C, Fernandes CR, Souza TP, Nora TTD. Aplicação da escala da dor em pacientes pós cirúrgicos. Revista Contexto \& Saúde [Internet], ljuí, 2011 Jan/Fev; 10(20): 669-72. Available from: https://www.revistas.unijui.edu.br/index.php/ contextoesaude/article/view/1621

26. Potter PA, Perry AG. Fundamentos de Enfermagem. 7. ed. Rio de Janeiro: Elsivier; 2009.

27. Bottega FH, Fontana RT. A dor como quinto sinal vital: Utilização da escala de avaliação por enfermeiros de um hospital geral. Texto Contexto Enferm [Internet], Florianópolis, 2010 Abr/Jun; 19(2): 283-90. DOI: http://dx.doi.org/10.1590/S010407072010000200009

28. Ribeiro NCA, Barreto SCC, Hora EC, Sousa RMC. O enfermeiro no cuidado à vítima de trauma com dor: o quinto sinal vital. Rev Esc Enferm USP [Internet], São Paulo, 2011 Mar; 45(1): 146-52. DOI: http://dx.doi.org/10.1590/S0080-62342011000100020

29. Gonçalves FHS, Pereira MGN, Cezar ES. Avaliação da intensidade da dor em pacientes submetidos a amigdalectomia. Cienc Cuid Saúde [Internet], 2007 Jan/Mar; 6(1): 85-94. DOI: http://dx.doi. org/10.4025/cienccuidsaude.v6i1.4979

30. Keller C, Paixao A, Moraes MA, Rabelo ER, Goldmeier S. Escala da dor: Implantação para pacientes em pós-operatório imediato de cirurgia cardíaca. Rev Esc Enferm [Internet], São Paulo, 2013 Jun; 47(3): 621-5. DOI: http://dx.doi.org/10.1590/S0080623420130000300014

31. Tomberg JO, Cantarelli KJ, Guanilo MEE, Dal Pai D. Acolhimento com avaliação e classificação de risco no Pronto Socorro: caracterização dos atendimentos. Cienc Cuid Saude [Internet], 2013 Jan/Mar; 12(1): 80-7. DOI: http://www.lume.ufrgs.br/ bitstream/handle/10183/94574/000913307.pdf?sequence=1
32. Souza CC, Mata LRF, Carvalho EC, Chianca TCM. Diagnósticos de enfermagem em pacientes classificados nos níveis I e II de prioridade do Protocolo Manchester. Rev Esc Enferm USP [Internet], São Paulo, 2013 Dec; 47(6): 1318-24. DOI: http://dx.doi.org/10.1590/S0080-623420130000600010

33. Ministério da Saúde (BR). Ministério da Saúde. Acolhimento e classificação de risco nos serviços de Urgência [Internet]. Secretaria de Atenção à Saúde, Política Nacional de Humanização da Atenção e Gestão do SUS. Brasília: Ministério da Saúde; 2009. Available from: http://bvsms. saude.gov.br/bvs/publicacoes/acolhimento classificaao risco servico urgencia.pdf

34. Grupo Brasileiro de Classificação de Risco (GBCR). O Sistema Manchester de Classificação de Risco [Internet]. 2015. Available from: http://www.gbcr.org.br/

35. Acosta AM, Duro CLM, Lima MADS. Atividades do Enfermeiro nos sistemas de triagem/classificação de risco nos serviços de urgência: Revisão Integrativa. Rev Gaúcha Enferm [Internet], Porto Alegre, 2012 Dec; 33(4): 181-90. DOI: http://dx.doi.org/10.1590/S1983-14472012000400023

\section{Publish in International Archives of Medicine}

International Archives of Medicine is an open access journal publishing articles encompassing all aspects of medical science and clinical practice. IAM is considered a megajournal with independent sections on all areas of medicine. IAM is a really international journal with authors and board members from all around the world. The journal is widely indexed and classified Q1 in category Medicine. 